\title{
The role of extracellular proteases enzyme in bacterial adherence
}

\author{
Sarab D. Alshamaa Muna M. Isaam Adeeba Y. Shreef \\ Department of Biology / College of Science \\ University of Mosul
}

Received

$\cdot 3 / 08 / 200 \wedge$
Accepted

08 / 01 / 2009

تم الكثف عن وجود الانزيمات الحالة للبروتين الخارج خلوية والتي لها فعالية تحليلية

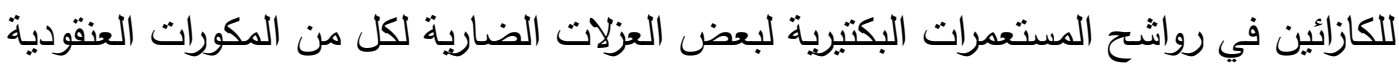

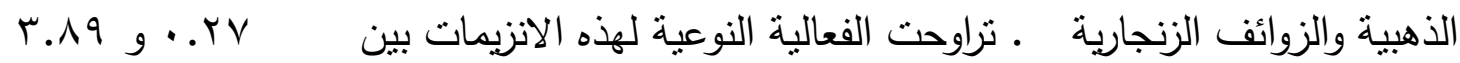

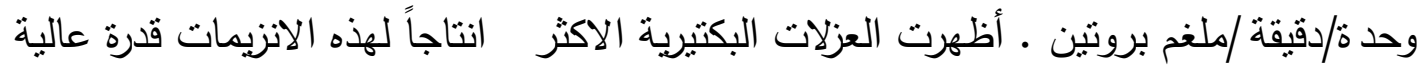
للالتصاق على كل من الخلايا الحرشفية المعزولة من الفم وانابيب الاختبار في حين ان العزلات

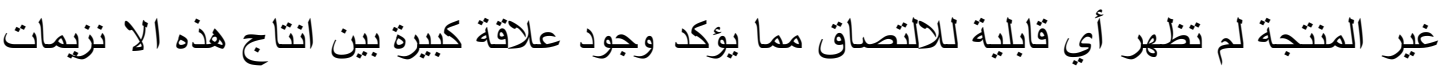

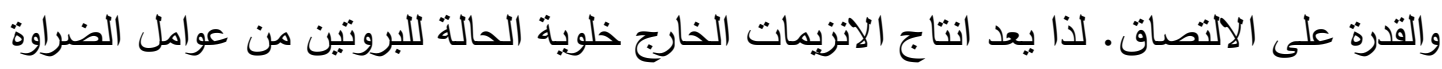
المهمة لانها تعتبر من عوامل الغزو المتعلقة بالتغذية والايض البكتيري.

\begin{abstract}
:
Extracellular proteases with caseinolytic activities were identified in culture supernatant of several pathogenic bacterial isolates of Staphylococcus aureus and Pseudomonas aeruginosa. Specific activities of these enzymes ranged from 0.27 to $3.89 \mathrm{unit} / \mathrm{min} / \mathrm{mg}$ protein. The most virulent isolates with high level of proteases production revealed great adherence ability to epithelial cells isolated from mouth and adherence to the tubes surface while others without any level of production of these enzymes didn't posses adherence ability. This proved the correlation between the production of these enzymes and bacterial adherence ability. Extracellular proteases considered very important virulence factors because it was important invasion factors related to bacterial nutrition and metabolism.
\end{abstract}




\section{Introduction :}

The first stage of microbial infection is colonization at the appropriate portal of entry. Pathogens usually colonize host tissues that are in contact with the external environment. Sites of entry in human host includes; the urogenital tract, the digestive tract, the respiratory tract ant the conjuctiva. Organisms that infect these regions have usually developed tissue adherence mechanism and some ability to over come or with stand the constant pressure of the host defenses. The production of extracellular substances facilitate invasion which encompasses mechanisms for colonization (1). Virulence factors assist pathogens in invasion and resistance of host defenses. Bacterial proteins with enzymatic activity e.g proteases, hyaluronidases nuraminidases, elastases, collagenases, facilitate local tissue spread, invasive organisms can penetrate and travers intact eukaryotic cells facilitating entry from mucosal surface (2).

IgA proteases may enable pathogen to subvert the antigen specificity of the humeral immune response to facilitate adhesive interaction and persistence on the mucosal surface (3) (Stinson and Levin 1993) (4). Demonstrated that Bacteriode gingivalis produce surface localized proteases that can degrade absorbed protein and may serve to un mask bacterial adhesine. (Naito and Gibons, 1988) (5) also found that the adherence of the bacteriod gingivalis to collagenous substrate is inhibited by both thoil protease and serum protease inhibitor.

The primary function of surface proteases is assumed to be for nutrient acquisition (6) have reported that $B$. gingivalis preferentially derives carbon nitrogen and energy from exogenous polypeptides. The numerous proteases or $P$. gingivalis allows the bacterium to hydrolyze a multitude of proteins encountered in the human host including those located on the surfaces of other oral bacteria.

The stce zinc metalloproteases is secreted by enterohemorrhagic E. coli (EHEC) $0157: \mathrm{H} 7$ and contribute to intimate adherence of this bacterium to host cells, a process essential for mammalian colonization (7).Pseudomonas aeruginosa is primarily a noaocomial and apportunistic pathogen that causes urinary tract infection, respiratory system infection, dermatitis, soft tissue infection bacteremia and avariety of systemic infections particularly in victim of severe burns, and in cancer and AIDS patient who are immuno suppressed. Staphylococcal infections are world wild increasing in all age group and it showed an increasing resistance to conventional antibiotics despite the availability of a wide range of these antibiotics.

For these reasons these two pathogens were chosen to demonstrate the correlation between the production of extracellular proteases and adheseveness of these two pathogens to epithelial cells and tube surface. 


\section{Material and Method :}

Bacterial strains 20 bacterial isolates 10 isolates for each one Staphylococcus aureus and pseudomonas aeruginosa which was isolated from severe skin infections had been taken from Al-Zahrawii teaching hospital in Mosul.

\section{Tests of adherence :}

For studing bacterial adhesion one of the earliest methods of (Christensen et al., 1982) (8) was utilized. For this procedure. Bacteria were grown in glass tube in a rich medium (trypticase soy broth). The medium was then removed and adherent bacteria are stained with safranin, the tubes are analyzed according to a visual scale (e.g weak + moderate ++ , strong +++ ) with this assay care could also be taken that the glass tubes used for the assays are not scratched. For bacterial adhesion to oral tissues epithelial cells isolated from mouth had been utilized to asses the test tube surface adhesion according to (Fiztegerald et al ., 1999) (9).

\section{Extracellular protease assays :}

Initially proteases activities were also detected by determination of gelatin liquefaction according to (10) in which $0.2 \mathrm{ml}$ culture supernatant was added to $2 \mathrm{ml}$ of $12 \%$ gelatin poured in tubes. Control to this test was done by adding $0.2 \mathrm{ml}$ of D.W. instead of culture super natant.

Proteolytic activity was assayed by using azocasein a substratc according to the method of (Secades and Guijarro, 1999) (11). Briefly, $120 \mathrm{Ml}$ of a suitable dilution of enzyme solution was added to $480 \mathrm{Ml}$ of azocasein $(1 \% \mathrm{wt} / \mathrm{vol})$ in reaction buffer (Triss buffer containing $\mathrm{mgcl}_{2}$ final concentration $5 \mathrm{mM}$ ) and the m3-5ixture was incubated at $300 \mathrm{c}$ for 30 min. The reaction was terminated by adding $600 \mathrm{Ml}$ of $10 \% \mathrm{vol} / \mathrm{wt}$ trichloroacetic acid and left for 30 min on ice followed by centrifugation at $15,000 \mathrm{xg}$ at $4 \mathrm{c}$ for $10 \mathrm{~min}$. eight hundred microliter of supernatant was neutralized by adding $200 \mathrm{Ml}$ of $1.8 \mathrm{~N} \mathrm{NaoH}$ and the absorbance at $420 \mathrm{~nm}$ (A 420) was measured using spectrophotometer. One unit of enzyme activity was defined as the amount which yielded an increase in A 420 of 0.01 in $30 \mathrm{~min}$ at $300 \mathrm{c}$.

The protein content of samples was estimated by the methods of (Lowry et al., 1951) (12) by using bovin serum albumin as a standard.

\section{Result and Discussion :}

Result of this study revealed that 7- bacterial isolates of $10(30 \%)$ Staphylococcus aureus and 4 of 10 (40\%) Pseudomonas aeruginosa showed adherence ability to the test tube surfaces which arranged between strong +++ and weak + as shown in (Table 1). These abilities accompanied with their abilities to produce intracellular proteases. 
bacterial isolates positive in liquefaction of gelatin test as shown in (Fig.1) revealed high specific activities of those enzymes ranged between $0.212-3.81 \mathrm{unit} / \mathrm{min} / \mathrm{mg}$ protein as shown in (Table 1) which also exhibited that bacterial isolates of both staphylococcus aureus and Pseudomonas aerurginosa had high specific activities also posses high adherence ability to both test tube surface as shown in (Fig. 2) and to epithelial cells which was isolated from mouth (Fig. 3). These results exhibited a correlation between the production of extracellular proteases enzyme and the adherence abilities of the pathogens which agreed with may other researchers demonstrating the role of proteases in adhesion. (Seddon et al., 1988) (13) reported that B. gingivalis preferentially derives carbon, nitrogen and energy from exogenous poly peptides by numerous protease enzymes which allows the bacterium to hydrolyze a multitude of proteins encountered in the human host. Surface proteases have evoled as a defense mechanism against fouling of the bacterial surface by host proteins (immunoglbulins, salivary proteins) fibrinogen. That it encounters in the mouth or the periodontal pocket. Absorbed proteins might mask adhesins necessary for colonization of the host by the bacterium or opsonize the bacteria for phagocytosis by neutrophils. To avoid fouling of its surface by host $B$. gingivalis produces surface located proteases that can degrade adsorbed proteins and may serve to unmask bacterial adhesions (5).

Bacteria possess a highly developed recognition system which is capable to recognizing and interacting with specific macromolecules on tissue surface. Furthermore correlation observed between attachment and colonization provided the first convincing that attachment was an essential step for bacterial colonization of host tissues (14).

Table 1 : Corrlation between the specific activities of proteases enzyme and the adherence abilities of bacterial isolates

\begin{tabular}{|l|c|c|c|}
\hline $\begin{array}{c}\text { Bacterial isolates } \\
\text { + ve in gelatin test }\end{array}$ & $\begin{array}{c}\text { Activities of } \\
\text { proteases unit/min }\end{array}$ & $\begin{array}{c}\text { Specific activities of } \\
\text { proteases enzyme } \\
\text { unit/min/mg protein }\end{array}$ & $\begin{array}{c}\text { Adherence } \\
\text { abilities }\end{array}$ \\
\hline Staphylococcus aureus 7 & 9.1 & 0.279 & +++ \\
\hline Staphylococcus aureus 8 & 7.8 & 0.433 & ++ \\
\hline Staphylococcus aureus 10 & 28.5 & 0.73 & +++ \\
\hline Pseudomonas aeruginosa 3 & 18.3 & 0.717 & +++ \\
\hline Pseudomonas aeruginosa 4 & 8.6 & 0.716 & ++ \\
\hline Pseudomonas aeruginosa 5 & 25.8 & 1.075 & +++ \\
\hline Pseudomonas aeruginosa 8 & 64.2 & 3.890 & +++ \\
\hline $\begin{array}{c}\text { Bacterial isolates } \\
\text { - ve in gelatin test }\end{array}$ & $\begin{array}{c}\text { Activities of } \\
\text { proteases unit/min }\end{array}$ & $\begin{array}{c}\text { Specific activities of } \\
\text { proteases enzyme } \\
\text { unit/min/mg protein }\end{array}$ & $\begin{array}{c}\text { Adherence } \\
\text { abilities }\end{array}$ \\
\hline $\begin{array}{l}\text { 7 Isolates of Staphylococcus } \\
\text { aureus }\end{array}$ & 0.0 & 0.0 & No adherence \\
\hline $\begin{array}{l}\text { 6 Isolates of } \text { pseudomonas } \\
\text { aeruginosa }\end{array}$ & 0.0 & 0.0 & No adherence \\
\hline
\end{tabular}

* One unit of enzyme activity was defined as the amount which yielded an increase in $\mathrm{A}_{420}$ of 0.01 in $30 \mathrm{~min}$ 
Sarab D. Alshamaa \& Muna M. Isaam \& Adeeba Y. Shreef

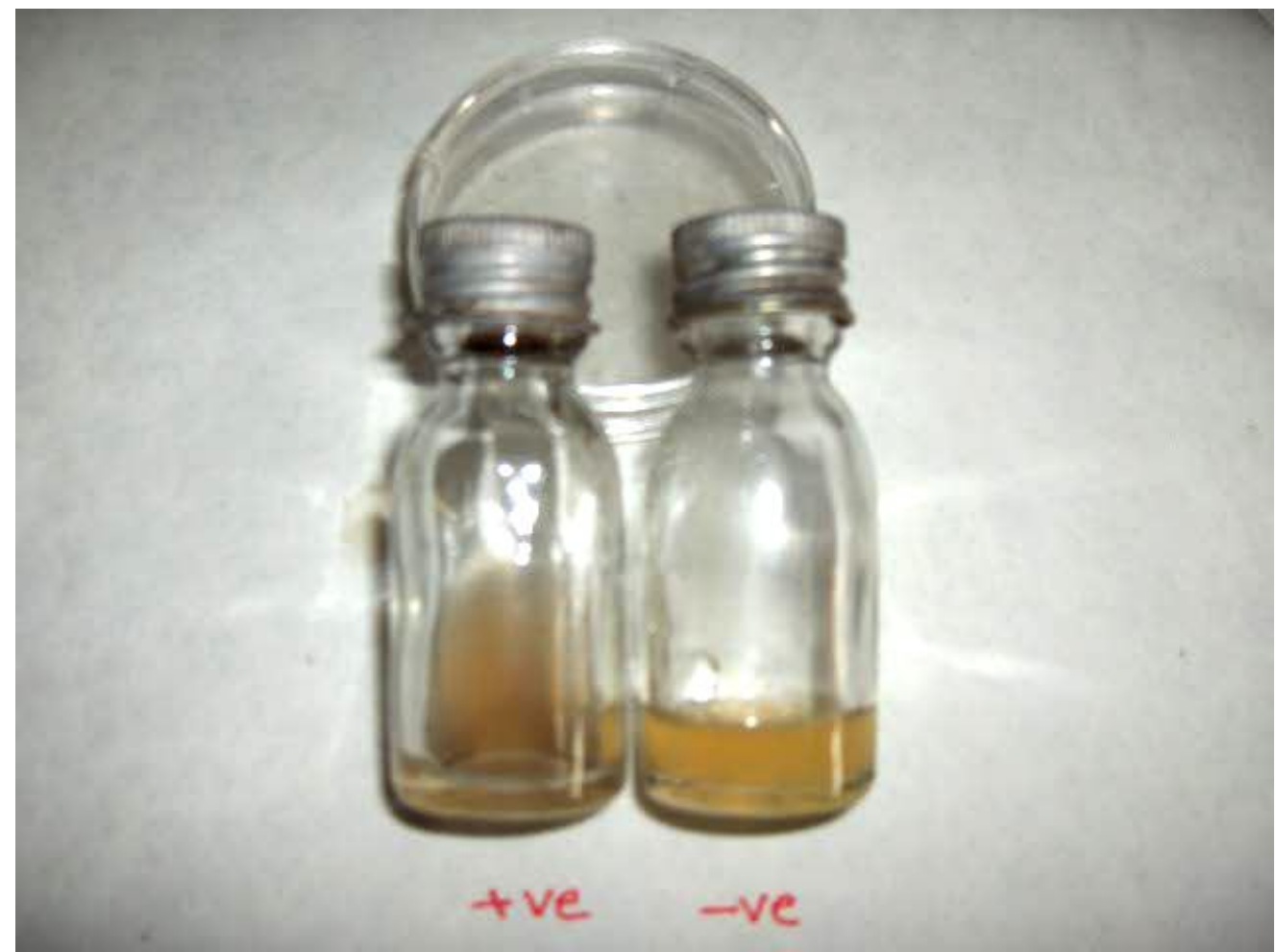

Fig. 1 : Liquefaction of gelatin test

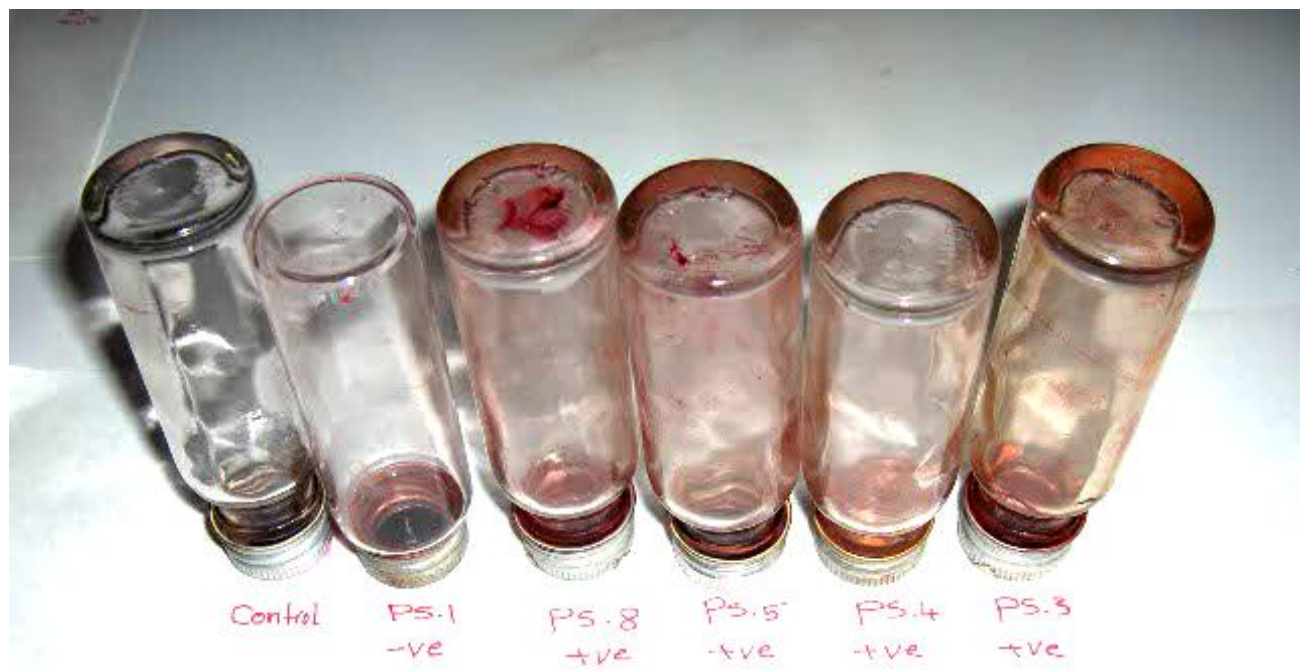

Fig. 2 : Adherence to tube surface test revealed the bacterial adherence abilities 


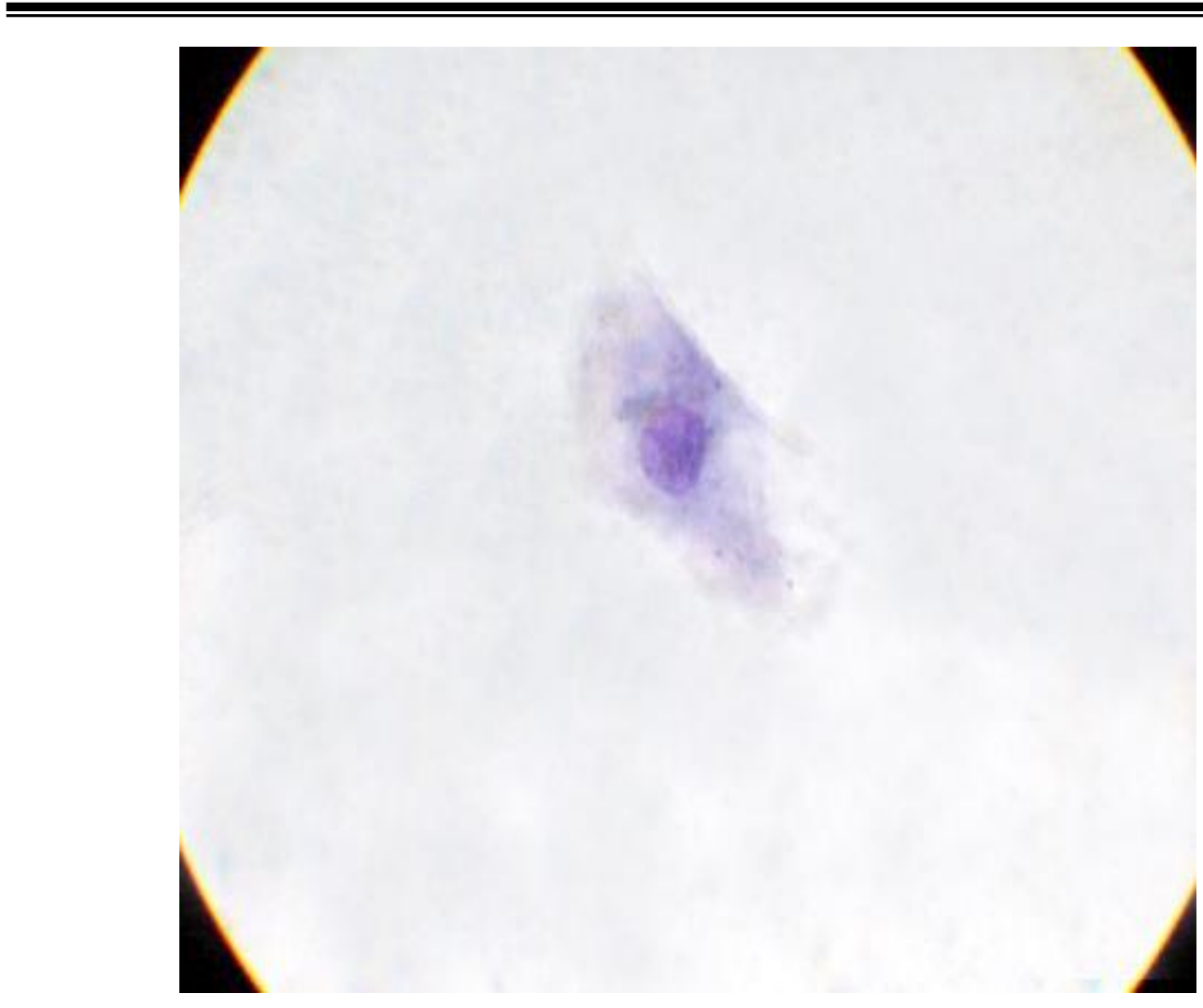

A
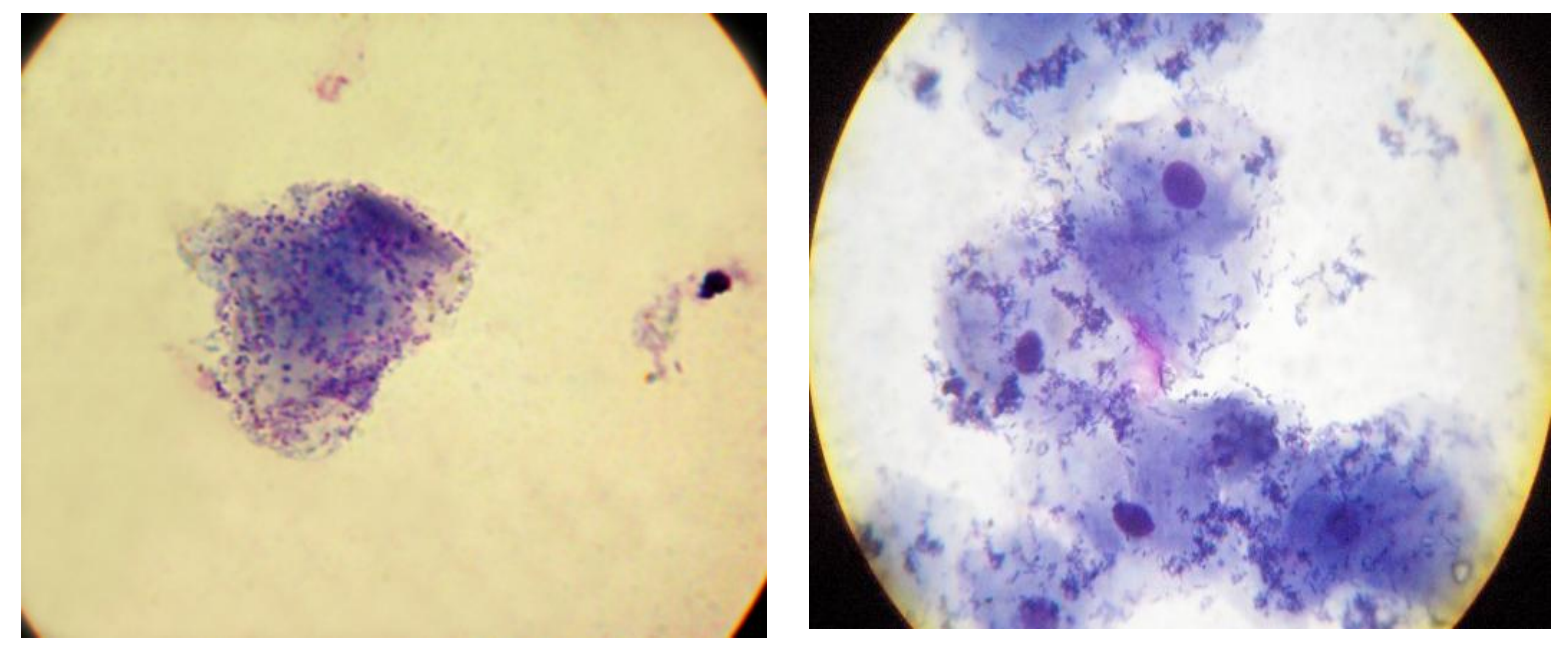

B

Fig 2 : Bacterial adherence to epithelial cells isolated from mouth

(Gemsa stain)

A : epithelial cell without bacterial adherence (Control)

B : bacterial adherence to epithelial cells 
Childs and Gibbons (1988) (15) suggested that elevated levels of enzymes, particularly neuraminidases and proteases, may contribute to this apparently increased susceptibility to colonization by periodontal pathogens. The role of protease. IV in the pathogenesis of pseudomonas aeruginosa keratitis was investigated by (Engel et al., 1997) (16) by comparing mutant strains completely deficient in protease IV activity with the protease Iv activity producing parent. A protease Iv deficient pseudomonas strain PA 103 - 29: Tn9 had significantly reduced corneal virulence relative to its parent strain PA $103-29$ in both rabbit intra stromel model and a mouse topical model of infection.

\section{References :}

1) Todar, K. "Microbial world" 2005. Mechanisms of bacterial pathogenicity. (C) kenaeth todar university of Wisconsin. Madison Department of Bacteriology.

2) Monual, M. P. 2005. "Biology of infectious disease" Factors Faciliting Microbial invasion Copyright 1995-2007. MERK co.

3) Weiser, T. N.; Bae, D.; Fasching, C.; Scamurra, R.W.; Ratner, A. J. and Janoff, E. N. 2003. Antibody - enhanced pneumococcal adherence requires lgA protease PNAS April 2003. 100: 4215.

4) Stinson, M. W. and Levin, M. J. 1993. Modulation of intergeneric adhesion of oral bacteria by human saliva. Critical Review in oral Biol. and med. $4: 309$.

5) Natio, Y. and Gibbons, R. J. 1988. Attachment of Bacteroides gingiralis to collagen ous substrate J. Dent. Res. $67: 1075$.

6) Shah, H. N. and William, A. D. 1987. Utilization of Glucose and amino acids by bacteroides intermedium and Bacteroides gingivalis. Curr Microbiol. 15: 241.

7) Grys, T. E.; Walters, L. L. and Welch, R. A. 2006. Characterization orf the StcE protrease activity of Escherichia Coli 0157: H7 J of Bacteriol. $6: 4646$.

8) Christensen, G. D.; Simpston, W. A.; Bisno A. I. and Beachery, E. H. 1982. Adherence of slim-producing strains of Staphylococcus epidermidis to smooth surface Infect. Immun. $37: 318$. 
9) Fitzgerald, M.; Murphy, S.; Muleahy, R.; Keanec, C. D. and Scott, T. 1999. Tissue culture adherence and heem - agglutination characteristic of Moraxella (Branhammella) Catarrhelis. FEMS. Immun. And Med. Microbiol. 24 : 105.

10) Vasil, M. L.; Liu, P. V. ans Lglewski, B. H. 1976. Temperature dependent Inactivating factor of Paseudomonas aeruginosa Exotoxin A, Infect and Immune. $13: 1467$.

11) Secades, P. and Cuijarro J. A. 1999. purification and characterization of an extracellular proteases from the fish pathogen Yerinia rucheri and effect of culture condition on production Appl. and Environm. Microbiol. September: 3969.

12) Lowry, O.H.; Rosebrouch, N. A.; Farr, A.L. and Randall R. I. 1951. Protein measurement with folin phenol reagent. J. Biol. Chem. 193: 205.

13) Seddon, S. V.; Shah, H. N.; Hardie, J. M. and Robinson, J. P. 1988. Chemically defined and minimal Media for Bacteroids gingivalis Vurr. Microbiol. $17: 147$.

14) Gibbons, R. j. and Van Houte, J. 1980. Bacterial adherence and the formation of Dental plaques in: Bacterial adherence E. H. Beachey, Ed., London: Chapman and Hall, pp. 61.

15) Child, W. C. and Gibbons, R.J. 1988. Use of percoll Density Gradient for studing the attachment of becteria to oral epithelial cells. J. Dent. Res. 67: 826.

16) Engel, L. S.; Hobden, J. A.; Moreau, J. M.; Callegan, M. C.; Hill, J. M. and O'callaghan, R. J. 1997. investigative ophthalmology and visual science 138: 1535. 